\title{
$19^{\text {тн }}$ International Symposium on Chironomidae, ČEské BuděJovice, Czech Republic, 17-22 August 2014
}

Every three years chironomists from across the world congregate to renew friendships, make new contacts and share their work in a convivial atmosphere: an experience that is compelling and results in repeated attendance symposium on symposium. This year the Symposium was hosted by the Faculty of Science, Charles University of Prague in collaboration with the Biology Centre of the Czech Republic in České Budějovice. About 80 chironomists converged on České Budějovice on Sunday $17^{\text {th }}$ August. Though time and fortune take their toll on the ability to attend, there were still four from my first symposium in Dublin (1979): Bruno Rossaro, Huberto Ferrarese, Paddy Ashe and myself. What is encouraging for the health of the study of chironomids is that the number attending successive symposia remains much the same: recruitment appears to be compensating for losses from the community.

Registration opened at 11.00 on the Sunday and closed at 17.00. My rather complex travel arrangements ensured that I arrived after registration had closed. Courtesy of a caretaker, I located the hall of residence, where, whilst booking in, I discovered others who had similarly arrived late. Too late for the tour of the brewery of Budweiser Budvar and "a" welcome drink, we made our way to a restaurant near the town centre. Hardly had we ordered, when in trouped about 20 delegates for whom liquid refreshment hadn't compensated for something solid. The swarming of chironomists at specific markers is inadequately researched, but one could start with Paddy's by now legendary maps!

On the Monday morning delegates were welcomed by Prof. Miloslav Simek, Director of the Biology Centre, Academy of Science of the Czech Republic, Prof. Libor Grubhoffer, Rector of the University of South Bohemia and Prof. Jan Frouz, Director of the Institute of Environment, Charles University, Prague. This was followed by the Thienemann lecture which was delivered by Takashi Okuda on 'Chironomids as important features in biological sciences'. The capacity of Polypedilum vanderplanki to dehydrate and rehydrate repeatedly without destruction is due to the replacement of water by trehalose, conserving the internal structure of cells in so doing and releasing the contents intact on hydration. I watched desiccated larvae of $P$. vanderplanki under a microscope rehydrate and resume activity as an undergraduate over half a century ago and have often wondered how they did it - now I know!

The oral presentations spanned three days with 42 papers delivered in three daily sessions, the sessions separated by lunch in the campus refectory and coffee breaks. The first of the sessions was on 'Kariology and genetics' with four presentations, three of them delivered by Veronika Golygina, impressive for the sustained clarity of her speech in a

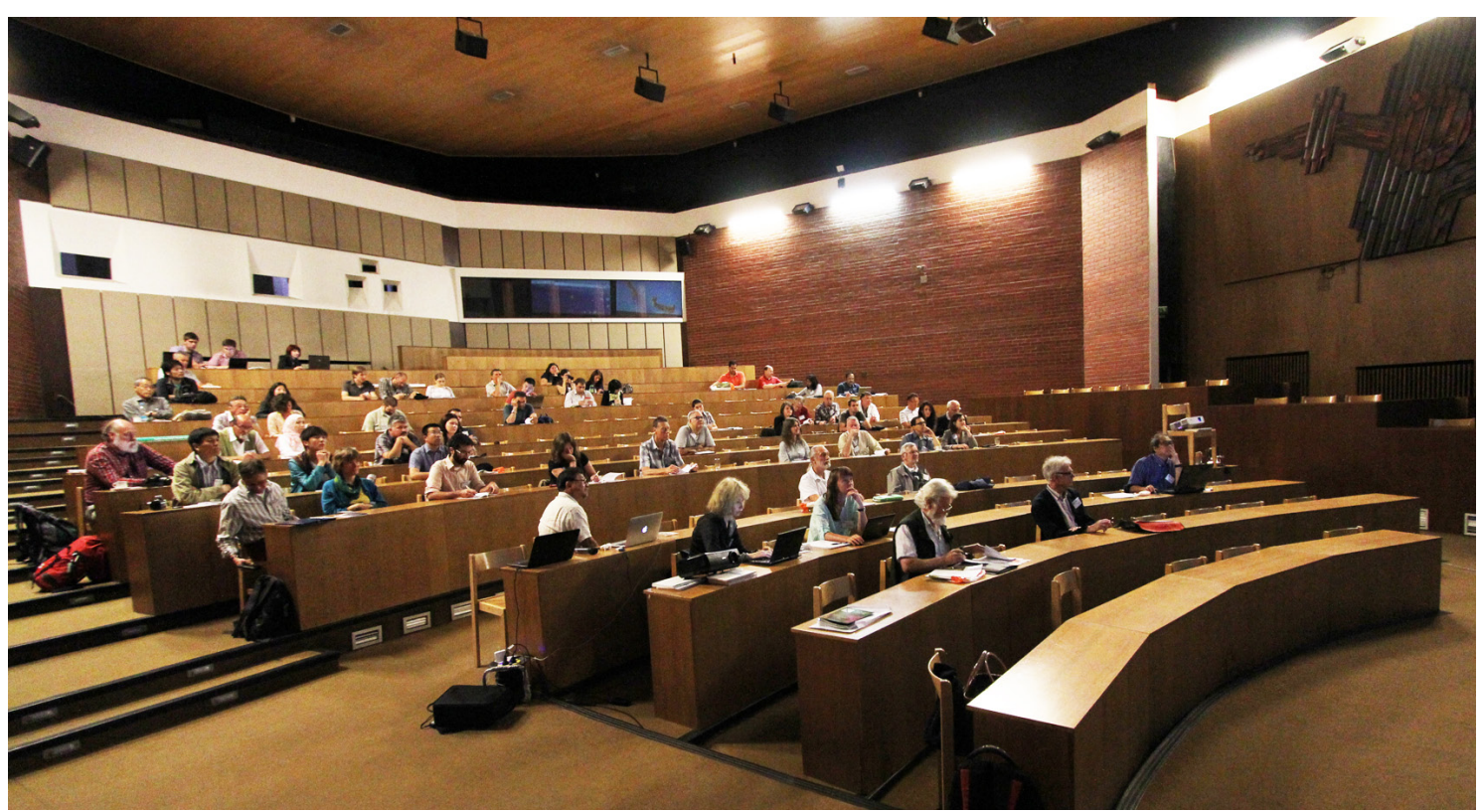

Lecture hall at the Biology Center of the Czech Academy and South Bohemia University. Photo: Andrey Przhiboro. 


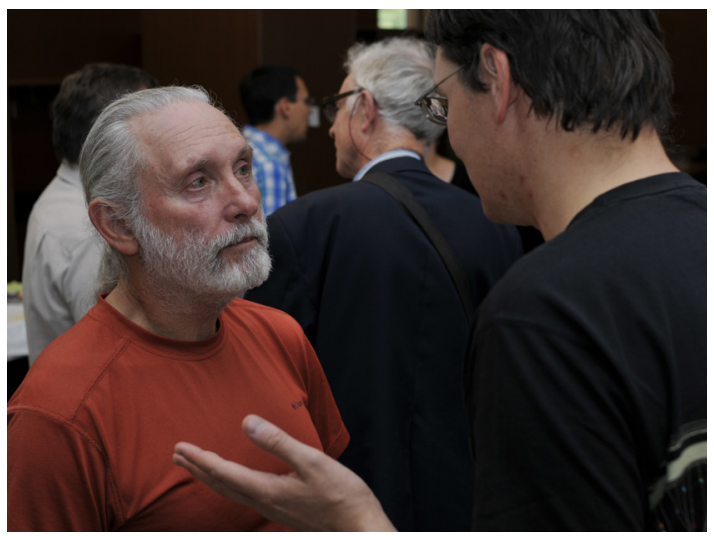

Len Ferrington and Andrey Przhiboro. Photo: Vít Syrovátka

language not her own. Then there were sessions on 'Physiology' (3 presentations) and 'Paleological implications ( 5 - fragments of larval head capsules continue to provide a variety of projects that provide information on the nature of aquatic habitats of former times).

In the lobby outside the lecture theatre 36 posters were displayed; eye catching and informative on a wide variety of Chironomidae related topics. These generated prolonged discussions on an individual basis, that a lecture cannot achieve and are invaluable for cementing contacts and sharing interests.

Tuesday saw sessions on 'Morphology, taxonomy and systematics' (7), 'Pollution and biomonito- ring' (4) and 'Autecology' (5) - that included an account of 'Orthocladiinae acuticauda/Orthocladius species aus Flußsand', the larva pointed at both ends to facilitate escape into mobile sand; this was accompanied by a video showing one doing just that!). The delegates then boarded coaches to be transported to Trěboň, where we were introduced to the history and technique of carp farming. The emptying of that enormous pond to harvest the fish must be an amazing spectacle! A very quick skim for exuviae, so as not to be left behind produced eight species including the ubiquitous Glyptotendipes paripes - the 'Symposium midge' (I have souvenir specimens of this species from many of the symposium venues and it was the only species I managed to collect in Tianjin!) We moved on to see the neo-gothic Schwartzenberg tomb: an impressive edifice in a tree filled park that was certainly worth the visit. Thence to a restaurant for the symposium banquet - a very enjoyable meal made all the more enjoyable by the company at the table. We were entertained by a very competent traditional jazz clarinet player. Did I really see delegates dancing?!

'Ecology spatiotemporal distribution' (4) and 'Community ecology' (10) comprised the sessions on the final day, that reported on projects from Japan through Icelandic cold springs to the high mountains of Brazil. Chironomidae please note: chironomists will find you wherever you are!

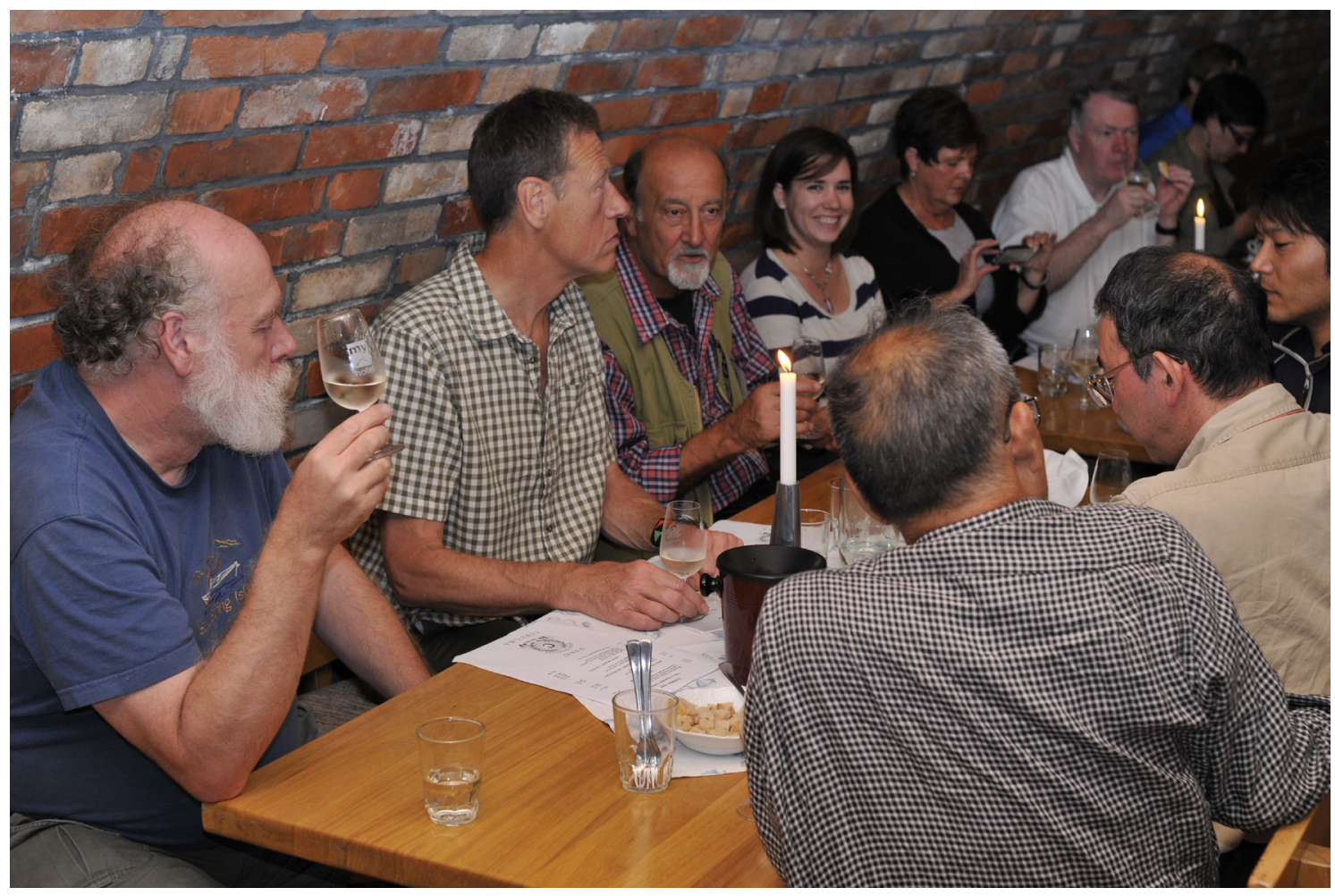

From the conference trip. Photo: Vít Syrovátka 
The final forum included a show of hands for a proposed change of name for the CHIRONOMUS Newsletter on Chironomidae Research to CHIRONOMUS Journal of Chironomidae Research, practically all delegates present voting in favour of the change, a minute's silence for those that had died since the last symposium, an update on the world catalogue by Paddy Ashe and thanks for the admirable arrangements by Jolana Tátosová, Peter Bitusík, Jan Frouz, Josef Matěna and Vít Syrovátka. I reiterate my personal thanks for their orchestration of events, conducted from the floor by Jan Frouz (he has the voice for it!).

It took six buses, five trains, five 'planes and two taxis to get to the Symposium and back. Was it worth the effort? Most decidedly: Yes! A friend of mine would end a meal with 'Well that's lunch; what's for supper?' At first I thought it rather rude after all the effort that his wife had made to produce the meal, but she understood it as a complement: 'If the next meal is as good as the one I've had, I can't wait!' We'll have to wait: Trento is not for another three years. Bruno and Huberto will be there; Paddy and I will complete the common denominator and look forward to seeing you all again: make the effort!

\section{Peter H. Langton}

16, Irish Society Court, Coleraine, Co. Londonderry, Northern Ireland BT52 $1 G X$.

E-mail: langtonph@gmail.com.

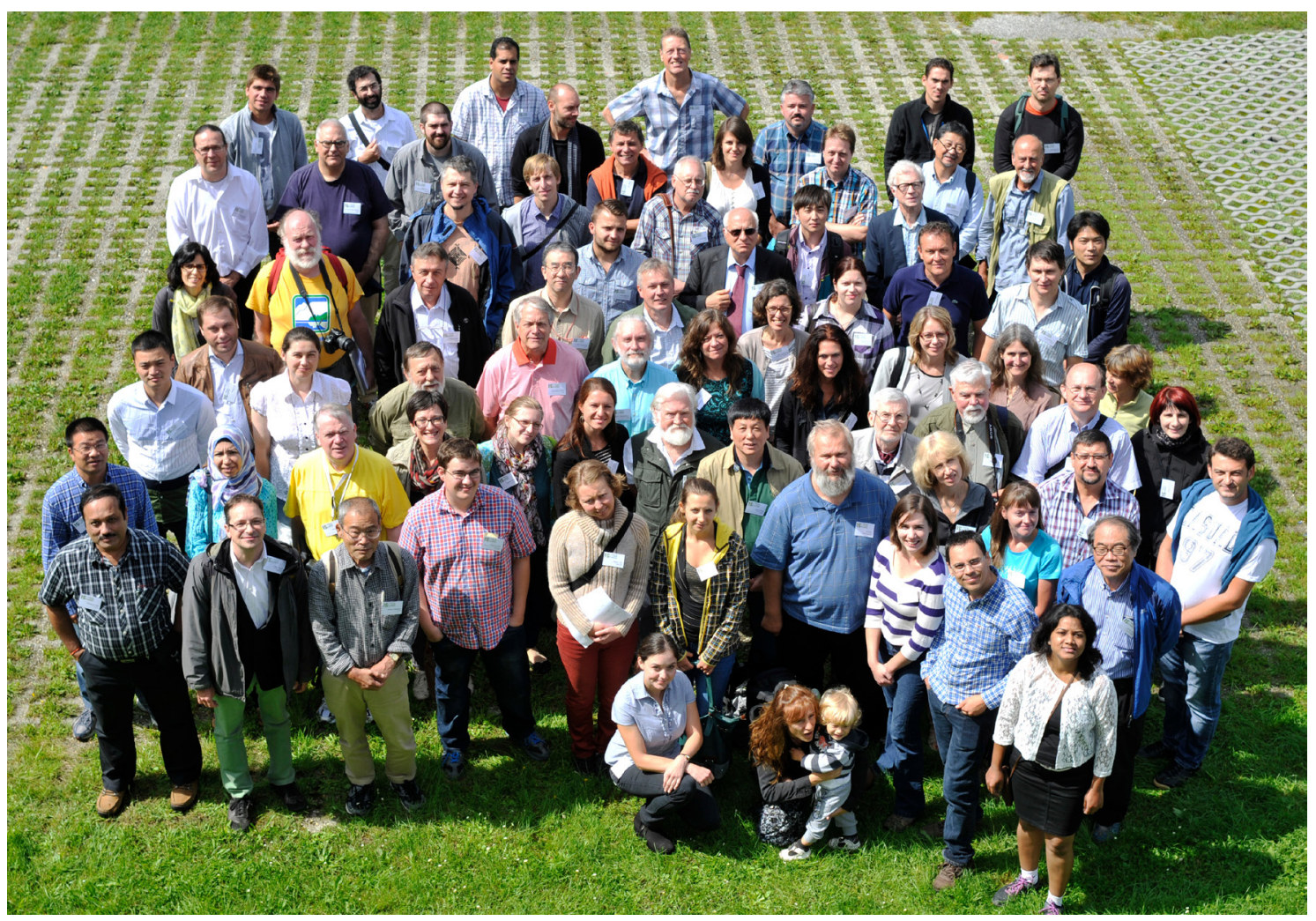

Participants at the 19th International Symposium on Chironomidae. Photo: Vít Syrovátka. 